\title{
Genetic Study of Native Grapevine Varieties of Northern, Western and Central Greece with the Use of Ampelographic and Molecular Methods
}

\author{
Katerina BINIARI, Maritina STAVRAKAKI* \\ Agricultural University of Athens, School of Agriculture, Engineering and Environmental Sciences, Department of Crop Science, Laboratory of \\ Viticulture, Iera Odos 75, 118 55, Athens, Greece; kbiniari@aua.gr; maritina@aua.gr (*corresponding author)
}

\begin{abstract}
The aim of this study was the identification and discrimination of 49 grapevine varieties that are cultivated in northern, western and central Greece with the use of the ampelographic description and the molecular method RAPD. The grapevine varieties were located in their cultivation centers and the studied samples were collected from productive vineyards of these regions. For the ampelographic description, 22 ampelographic characters were used following a list of descriptors developed by the International Organization of Vine and Wine (OIV), while for the molecular analysis 8 of the most polymorphic primers were used. The results showed that: (a) there is high degree of genetic heterogeneity among most of the varieties studied, (b) grapevine varieties 'Xinomavro' and 'Zalovitiko' exhibited identity with both methods used, therefore the latter constitutes a synonym/clone of the former, (c) high degree of genetic similarity was recorded between cv 'Stavroto' and 'Abelakiotiko', a result enhancing the view that they constitute biotypes/clones of an original/parent variety and originated through the accumulation of mutations, (d) a previous hypothesis is confirmed. This hypothesis states that in the vineyards of northern Greece, different varieties of Vitis vinifera L. as well as hybrids (direct producers) were imported. Names/synonyms were given to these imported varieties and hybrids related to their place of origin or the morphological traits of the grape/berries implying identity among them ('Mavroudi', 'Voulgariko', 'Voulgaroudia', 'Vapsa' etc.), while they are different varieties, (e) the combination of the ampelographic description and the molecular method RAPD is very effective in the identification and discrimination of grapevine cultivars.
\end{abstract}

Keywords: genetic diversity; grapevine cultivar; phenotyping; RAPD; Vitis vinifera L.

Abbreviations: PDO-Protected Designation of Origin; PGI-Protected Geographical Indication; RAPD - Random Amplified Polymorphic DNA

\section{Introduction}

More than 70 grapevine varieties are reported to be cultivated in central, western and northern Macedonia (Thessaly, Epirus, Macedonia, Thrace), of which a relatively large number of are considered to be indigenous (Ministry of Rural Development and Food, 2017). In the present work, 49 grapevine varieties from the above-mentioned regions were chosen to be studied, 36 of which for the first time. The studied samples were collected from productive vineyards of these regions, while the names of the varieties were maintained as found in the various cultivation centers. The 49 studied varieties can be divided in three groups, depending on their origin as well as on their viti-viniculture importance.

The first group consists of indigenous varieties that have been cultivated since many years in these viticultural regions and constitute the base of many PDO (Protected Designation of Origin) and PGI (Protected Geographical Indication) wines, such as 'Xinomavro', 'Limnio', 'Moschomavro', 'Stavroto', 'Abelakiotiko', 'Krassato', 'Vlachiko', 'Bekari', 'Priknadi' etc. (Ministry of Rural Development and Food, 2017).

The second group consists of varieties mainly of eastern origin, such as 'Karnachalades', 'Papas-kara', 'Sefka', 'Pamidi', 'Zoumiatiko', 'Keratsouda', as well as the various 'Mavroudia'. Grapevine varieties 'Karnachalades' and 'Papas-Kara' were cultivated in eastern Rumelia and because of the deep-colored skin of the berries, Greek viticulturists called them 'Bogia' and 'Bogialamas' (from the Turkish words boya, boyama = paint, color) (Hatziparaskevas, 1937/38; Stavrakakis, 2017).

The third group consists of varieties of unknown origin, such as 'Aleponoura', 'Alpitsa' etc. and some 'Asproudia' that are locally cultivated. Many of these varieties are either 
not included in the Greek National Catalogue of Grapevine Varieties ('Alpitsa', 'Kokkinouska', 'Nevro', 'Nigrikiotiko', 'Pach(i)pectsi', 'Piknassa', 'Vergiotiko') or they are hybrids (direct producers) that have been imported in northern Greece under various names ('Tzortzidika', 'Galliko', 'Vapsa', 'Vaftra', etc.). It is worth mentioning that some of these varieties are not preserved in the Ampelographic Collections of Greece, while in some cases, there are significant differences in the ampelographic characters between the varieties located and studied in productive vineyards and the one preserved in the ampelographic collections. For example, grapevine variety 'Alpitsa' which is cultivated in western Macedonia is white, contrary to the one in the Ampelographic Collection of NAGREF which is red, while opinions are divided when it comes to the typical sample of grapevine variety 'Krassato'.

'Xinomavro' is the noblest grapevine variety of the Macedonian vineyard and constitutes the base of PDO wines (Amynteo, Goumenissa, Naoussa, Rapsani) (Kourakou, 2017). In the present work, the representative biotype of grapevine variety 'Xinomavro' from the viticultural area of Naoussa was studied, compared to grapevine variety 'Zalovitiko' that exhibits similar ampelographic characters (Stavrakakis et al., 2018).

Red grapevine variety 'Limnio' (synonym 'Kalabaki') is considered one of the oldest of the vineyard of northern Greece, originating from the island of Limnos. It is believed to have been cultivated since the $5^{\text {th }}$ century BCE, while it is mentioned by Polydefkis ( $2^{\text {nd }}$ century CE) as Limnia grape. It participates in the production of PDO wine Slopes of Meliton (together with 'Cabernet Sauvignon', 'Cabernet Franc').

Grapevine variety 'Moschomavro' (also known as 'Moschogaltso') is considered to be of polyclonal nature, and it owes the first part of its name to the aromatic character of its must.

Grapevine varieties 'Stavroto' and 'Abelakiotiko' are considered to be closely related and/or synonyms (Ministry of Rural Development and Food, 2017). 'Stavroto' was cultivated mainly in the vineyards of the historic community Abelakia, and from there, one or more biotypes were transferred in the viticultural areas of Rapsani and as is usually the case, it took the name of the region of origin (abelakiotiko $=$ the one coming from Abelakia). Respectively, grapevine variety 'Xinomavro' in the area of Rapsani was called 'Naoustiano' (as the one originating from Naoussa, the first cultivation center of this variety). The name 'Stavroto' (from the Greek word stavros = cross) can be attributed to the shape of the grape, whose two first diversifications are significantly developed and give the shape of the cross (Krimbas, 1944; Stavrakakis et al., 2018).

Grapevine variety 'Krassato' is cultivated exclusively in the greater area of Rapsani and is co-macerated with grapevine varieties 'Xinomavro' and 'Stavroto' for the production of the PDO red wine Rapsani. The name krassato (= winy, wine-colored) is connected either with the fact that the variety is characterized as primarily appropriate for wine production or with the color of the skin of the berries that refers to the Homer's adjective of the sea (Alexiou, 1986; Lambert-Gòcs, 1990).

Grapevine varieties 'Pamidi' (synonyms 'Pamid', 'Plovdiska', 'Dorukata' etc.) and 'Sefka' (synonym
'Nicheftka') are of eastern origin; they have been cultivated for many years in Thrace and participate in the production of PGI wines (Vlachos, 1986). Grapevine variety 'Zoumiatiko' (synonyms 'Dimyat', 'Smederevka') is considered to originate from the Egyptian city Dimyat, to which it owes its name (Logothetis and Vlachos, 1966), while the Greek name derives from the Greek word "Yovuiv" and suggests the high must concentration of the berry (Stavrakakis, 2010).

Grapevine variety 'Debina' is cultivated exclusively in Epirus for the production of the PDO wine Zitsa, while grapevine variety 'Malagousia' - one of the most important varieties of the vineyard of southern Greece - was transferred and has been cultivated in recent years in various areas of northern Greece for the production of varietal wines.

Red grapevine variety 'Vlachiko' is cultivated mainly in Epirus and it most likely owes its name to the Vlachous (vlachos and vlachikos: raw, hardy) (Krimbas, 1949; Stavrakakis et al., 2018), and together with grapevine variety 'Bekari' they participate in the production of PGI wines Epirus, Ioannina, Metsovo, Meteora.

Grapevine variety 'Keratsouda' (synonym 'Tenedio', as it originated from the island of Tenedos) owes its name to the attractiveness of the grapes with the reddish berries (from the Greek idiomatic word kyratsouda or keratsouda = the young, beautiful lady, girl) (Stavrakakis et al., 2018). The rest of the varieties are cultivated in small surface areas and are of local interest.

The present work is part of a broader research project for the study and evaluation of Greek grapevine varieties, aiming to investigate the genetic diversity of grapevine varieties cultivated in central, western and northern Greece.

\section{Materials and Methods}

\section{Plantmaterial}

Forty-nine (49) grapevine varieties (Vitis vinifera L.) were chosen for identification using the ampelographic description and the molecular method RAPD (Random Amplified Polymorphic DNA). The studied varieties, their special characters and the areas from where the samples were collected are presented in detail in Table 1.

\section{Ampelographic and molecular methods}

For the ampelographic description, twenty-two (22) ampelographic characters were used and measured on each grapevine cultivar, following a list of descriptors developed by the International Organization of Vine and Wine (OIV, 2009) including the preliminary minimal traits relative to shoot, mature leave, bunch etc. among others (Table 2). The ampelographic characters have proven to be quite effective in the discrimination of grapevine varieties, as shown in previous studies (Rusjan et al., 2015; Stavrakaki and Biniari 2016; Stavrakaki and Biniari 2017).

For the RAPD molecular analysis, from a total of sixteen (16) primers (random decamer oligonoucleotides) that were tested, eight (8) of the most polymorphic ones were chosen and used to amplify genomic DNA through the Polymerase Chain Reaction (PCR) in order to identify and discriminate the selected varieties (Table 3 ). 
48

Table 1. Cultivars studied and sampling areas

\begin{tabular}{|c|c|c|c|c|}
\hline$a / a$ & Cultivar $^{a}$ & Berry color ${ }^{b}$ & $\mathrm{Use}^{\mathrm{c}}$ & Sampling region ${ }^{\mathrm{d}}$ \\
\hline 1 & Aleponoura & B & $\mathrm{W}$ & Thr (Soufli) \\
\hline 2 & Aleponoura-1 & $\mathrm{N}$ & W & wM (Pelekanos) \\
\hline 3 & Alpitsa & B & W & wM (Velvendos) \\
\hline 4 & Abelakiotiko & $\mathrm{N}$ & W & Th (Rapsani) \\
\hline 5 & Aspro aromatiko & B & W & wM (Siatista) \\
\hline 6 & Aspro myrodato & B & W & Thr (Soufli) \\
\hline 7 & Aspro psilorrogo & B & W & Thr (Pentalofos) \\
\hline 8 & Bekari & $\mathrm{N}$ & W & $\mathrm{E}(\mathrm{Zitsa})$ \\
\hline 9 & Bogialamades & $\mathrm{N}$ & W & Thr (Soufli) \\
\hline 10 & Debina & B & W & $\mathrm{E}(\mathrm{Zitsa})$ \\
\hline 11 & Fokiano & Rs & W & Thr (Soufli) \\
\hline 12 & Galliko & $\mathrm{N}$ & W & wM (Pelekanos) \\
\hline 13 & Gountabi & $\mathrm{N}$ & W & E (Metsovo) \\
\hline 14 & Karnachalades & $\mathrm{N}$ & W & Thr (Soufli) \\
\hline 15 & Keratsouda & Rs & $\mathrm{W} / \mathrm{T}$ & Thr (Soufli) \\
\hline 16 & Kokkinouska & Rs & $\mathrm{W} / \mathrm{T}$ & wM (Pelekanos) \\
\hline 17 & Krassato & $\mathrm{N}$ & W & Th (Rapsani) \\
\hline 18 & Limnio & $\mathrm{N}$ & W & cM (Chalkidiki) \\
\hline 19 & Malagousia & B & W & cM (Chalkidiki) \\
\hline 20 & Mavro aromatiko & $\mathrm{N}$ & W & Thr (Pentalofos) \\
\hline 21 & Mavroudi & $\mathrm{N}$ & W & E (Metsovo) \\
\hline 22 & Moschomavro-1 & $\mathrm{N}$ & W & wM (Velvendos) \\
\hline 23 & Moschomavro-2 & $\mathrm{N}$ & W & wM (Siatista) \\
\hline 24 & Negoska & $\mathrm{N}$ & W & cM (Goumenissa) \\
\hline 25 & Nevro & $\mathrm{N}$ & W & wM (Pelekanos) \\
\hline 26 & Nigrikiotiko-1 & $\mathrm{N}$ & W & wM (Siatista) \\
\hline 27 & Nigrikiotiko-2 & $\mathrm{N}$ & W & wM (Siatista) \\
\hline 28 & Ntopio Metsovou & $\mathrm{N}$ & W & E (Metsovo) \\
\hline 29 & Pamidi & Rs & W & Thr (Soufli) \\
\hline 30 & Papas-kara & $\mathrm{N}$ & W & Thr (Dikaia) \\
\hline 31 & Pach(i)petsi & $\mathrm{N}$ & W & E (Metsovo) \\
\hline 32 & Piknassa & B & W & E (Metsovo) \\
\hline 33 & Priknadi & B & W & cM (Naoussa) \\
\hline 34 & Salonikio & $\mathrm{N}$ & W & $\mathrm{wM}, \mathrm{cM}$ \\
\hline 35 & Sefka-1 & $\mathrm{N}$ & W & Thr (Pentalofos) \\
\hline 36 & Sefka-2 & $\mathrm{N}$ & W & Thr (Soufli) \\
\hline 37 & Sklithro & $\mathrm{N}$ & W & wM (Siatista) \\
\hline 38 & Stavroto & $\mathrm{N}$ & W & Th (Rapsani) \\
\hline 39 & Tzortzidika & $\mathrm{N}$ & W & E, Thr \\
\hline 40 & Tsougiannides & B & $\mathrm{W} / \mathrm{T}$ & Thr (Soufli) \\
\hline 41 & Vapsa Naoussas & $\mathrm{N}$ & W & cM (Naoussa) \\
\hline 42 & Vergiotiko & $\mathrm{N}$ & $\mathrm{W} / \mathrm{T}$ & wM (Velvendos) \\
\hline 43 & Vlachiko & $\mathrm{N}$ & W & $\mathrm{E}(\mathrm{Zitsa})$ \\
\hline 44 & Voulgariko-1 & $\mathrm{N}$ & W & wM (Pelekanos) \\
\hline 45 & Voulgariko-2 & $\mathrm{N}$ & W & wM (Siatista) \\
\hline 46 & Voulgaroudia & $\mathrm{N}$ & W & Thr (Soufli) \\
\hline 47 & Xinomavro & $\mathrm{N}$ & W & cM (Naoussa) \\
\hline 48 & Zalovitiko & $\mathrm{N}$ & W & Th (Karditsa) \\
\hline 49 & Zoumiatiko & B & W & cM (Serres) \\
\hline
\end{tabular}

a. Transliteration of the original Greek name of cultivar into Latin characters [as written in the National Catalogue]

b. N: black/red (Noir), Rs: pink (Rosé), B: white (Blanc) [as written in the OIV]

c. W: wine, T: table

d. E: Epirus, cM: Central Macedonia, wM: Western Macedonia, Th: Thessaly, Thr: Thrace 
Table 2. Ampelographic characteristics, based on the OIV descriptors list (OIV, 2009)

\begin{tabular}{|c|c|c|c|c|c|}
\hline Code & Ampelographic characteristic & Notes & Code & Ampelographic characteristic & Notes \\
\hline 001 & $\begin{array}{l}\text { Young shoot: opening of the } \\
\text { shoot tip }\end{array}$ & $\begin{array}{l}\text { 1: closed, } 3 \text { : half open, } \\
\text { 5: fully open }\end{array}$ & 004 & $\begin{array}{l}\text { Young shoot: density of } \\
\text { prostrate hairs on tip }\end{array}$ & $\begin{array}{c}\text { 1: none or very low, } 3: \text { low, } \\
\text { 5: medium, } 7: \text { high, } 9: \text { very } \\
\text { high }\end{array}$ \\
\hline 016 & $\begin{array}{l}\text { Shoot: number of consecutive } \\
\text { tendrils }\end{array}$ & $\begin{array}{c}1: 2 \text { or less, } 2: 3 \text { or } \\
\text { more }\end{array}$ & 051 & $\begin{array}{l}\text { Young leaf: color of the } \\
\left.\text { upper side of blade ( } 4^{\text {th }} \text { leaf }\right)\end{array}$ & $\begin{array}{l}\text { 1: green, } 2 \text { : yellow, } 3 \text { : } \\
\text { bronze, } 4 \text { : copper-reddish }\end{array}$ \\
\hline 053 & $\begin{array}{c}\text { Young leaf: density of } \\
\text { prostrate hairs between main } \\
\text { veins on lower side of blade } \\
\left.\text { ( } 4^{\text {th }} \text { leaf }\right)\end{array}$ & $\begin{array}{c}\text { 1: none or very low, } 3 \text { : } \\
\text { low, 5: medium, } 7 \text { : } \\
\text { high, 9: very high }\end{array}$ & 055 & $\begin{array}{c}\text { Young leaf: density of } \\
\text { prostrate hairs on main veins } \\
\text { on lower side of blade ( } 4^{\text {th }} \\
\text { leaf) }\end{array}$ & $\begin{array}{c}\text { 1: none or very low, 3: low, } \\
5: \text { medium, } 7: \text { high, } 9: \text { very } \\
\text { high }\end{array}$ \\
\hline 067 & Mature leaf: shape of blade & $\begin{array}{l}\text { 1: cordate, } 2 \text { : wedge- } \\
\text { shaped, } 3 \text { : pentagonal, } \\
\text { 4: circular, } 5: \text { kidney- } \\
\text { shaped }\end{array}$ & 068 & Mature leaf: number of lobes & $\begin{array}{c}\text { 1: one (entire leaf), } 2: \text { three, } \\
\text { 3: five: } 4 \text { : seven, } 5: \text { more } \\
\text { than seven }\end{array}$ \\
\hline 070 & $\begin{array}{c}\text { Mature leaf: area of } \\
\text { anthocyanin coloration of main } \\
\text { veins on upper side of blade }\end{array}$ & $\begin{array}{l}\text { 1: absent, } 2 \text { : only at the } \\
\text { petiolar point, } 3 \text { : up to } \\
\text { the } 1^{\text {st }} \text { bifurcation, } 4 \text { : } \\
\text { up to the } 2^{\text {nd }} \\
\text { bifurcation, } 5 \text { : beyond } \\
\text { the } 2^{\text {nd }} \text { bifurcation }\end{array}$ & 075 & $\begin{array}{l}\text { Mature leaf: blistering of } \\
\text { upper side of blade }\end{array}$ & $\begin{array}{c}\text { 1: absent or very weak } 3 \text { : } \\
\text { weak, 5: medium, 7: strong, } \\
\text { 9: very strong }\end{array}$ \\
\hline 076 & Mature leaf: shape of teeth & $\begin{array}{l}\text { 1: both sides concave, } \\
\text { 2: both sides straight, } \\
\text { 3: both sides convex, } \\
\text { 5: one side concave, } \\
\text { one side convex, } 5 \text { : } \\
\text { mixture between notes } \\
2 \& 3\end{array}$ & 079 & $\begin{array}{l}\text { Mature leaf: degree of } \\
\text { opening / overlapping of } \\
\text { petiole sinus }\end{array}$ & $\begin{array}{l}\text { 1: very wide open, } 3: \text { open, } \\
\text { 5: closed, 7: overlapped, 9: } \\
\text { strongly overlapped }\end{array}$ \\
\hline 080 & $\begin{array}{l}\text { Mature leaf: shape of base of } \\
\text { petiole sinus }\end{array}$ & $\begin{array}{l}\text { 1: U-shaped, 2: brace- } \\
\text { shaped, 3: V-shaped }\end{array}$ & $081-2$ & $\begin{array}{l}\text { Mature leaf: petiole sinus } \\
\text { base limited by veins }\end{array}$ & $\begin{array}{l}\text { 1: not limited, 2: on one } \\
\text { side, 3: on both sides }\end{array}$ \\
\hline 084 & $\begin{array}{c}\text { Mature leaf: density of } \\
\text { prostrate hairs between the } \\
\text { main veins on lower side of } \\
\text { blade }\end{array}$ & $\begin{array}{l}\text { 1: none or very low, } \\
\text { 3: low, 5: medium, } 7 \text { : } \\
\text { high, 9: very high }\end{array}$ & 086 & $\begin{array}{l}\text { Mature leaf: density of } \\
\text { prostrate hairs on main veins } \\
\text { on lower side of blade }\end{array}$ & $\begin{array}{c}\text { 1: none or very low, } 3: \text { low, } \\
\text { 5: medium, } 7: \text { high, } 9: \text { very } \\
\text { high }\end{array}$ \\
\hline 087 & $\begin{array}{l}\text { Mature leaf: density of erect } \\
\text { hairs on main veins on lower } \\
\text { side of blade }\end{array}$ & $\begin{array}{l}\text { 1: none or very low, } \\
\text { 3: low, 5: medium, } 7 \text { : } \\
\text { high, 9: very high }\end{array}$ & 093 & $\begin{array}{c}\text { Mature leaf: length of petiole } \\
\text { compared to length of middle } \\
\text { vein }\end{array}$ & $\begin{array}{l}\text { 1: much shorter, } 3 \text { : slightly } \\
\text { shorter, 5: equal, 7: slightly } \\
\text { longer, 9: much longer }\end{array}$ \\
\hline 208 & Bunch: shape & $\begin{array}{l}\text { 1: cylindrical, } \\
\text { 2: conical, } 3 \text { : funnel } \\
\text { shaped }\end{array}$ & 223 & Berry: shape & $\begin{array}{l}\text { 1: obloid, 2: globose, } 3 \text { : } \\
\text { broad ellipsoid, 4: narrow } \\
\text { ellipsoid, 5: cylindric, } 6 \text { : } \\
\text { obtuse ovoid, 7: ovoid, 8: } \\
\text { obovoid, 9: horn shaped, 10: } \\
\text { finger shaped }\end{array}$ \\
\hline 225 & Berry : color of skin & $\begin{array}{l}\text { 1: green yellow, } \\
\text { 2: rose, 3: red, 4: grey, } \\
\text { 5: dark red violet, } \\
\text { 6: blue black }\end{array}$ & 231 & $\begin{array}{l}\text { Berry: intensity of flesh } \\
\text { anthocyanin coloration }\end{array}$ & $\begin{array}{c}\text { 1: none or very weak } 3 \text { : } \\
\text { weak, 5: medium, } 7 \text { : strong, } \\
\text { 9: very strong }\end{array}$ \\
\hline
\end{tabular}

As plant material, young and fully expanded leaves from the main shoots were used. In the vines from where the leaves were taken, the health of the vines was evaluated macroscopically, both during the vegetation period as well as during full maturation of the grapes, in order to locate and select healthy biotypes. From each vine, three samples were collected which were place in dried ice $\left(-80{ }^{\circ} \mathrm{C}\right.$ approximately) and were then stored in deep freeze $\left(-80^{\circ} \mathrm{C}\right)$.

Grapevine DNA was extracted from the young and fully expanded leaves followed by the same amplification conditions and gel electrophoresis preparation, as described in Stavrakakis et al. (1997).
Table 3. Primers used for RAPD molecular analysis

\begin{tabular}{ccc}
\hline Primer Code & Sequence & $\begin{array}{c}\text { Number of Amplified } \\
\text { Fragments }\end{array}$ \\
\hline 1224 & CAGGCCCTTC & 17 \\
1225 & AGGTGACCGT & 14 \\
1226 & CGCAGGATGG & 14 \\
1227 & GTGTGCCCCA & 11 \\
OPM 01 & GTTGGTGGCT & 21 \\
OPM 06 & CTGGGCAACT & 20 \\
OPM 12 & GGGACGTTGG & 13 \\
OPF 05 & CCGAATTCCC & 19 \\
\hline
\end{tabular}


50

\section{Data analysis}

For the statistical analysis, relationships among the OIV descriptors (parameters) were studied using the statistical program JMP (JMP v. 10 statistical software, SAS Institute Inc., Cary, NC, USA). Principal Component (PC) analysis was used to evaluate the most important parameters that contributed to the biotype separation into different groups according to their morphological traits (OIV descriptors).

For the statistical analysis of the ampelographic and the molecular data, the method UPGMA was used with one dissimilarity/distance coefficient and one similarity coefficient, respectively. In order to present the morphological relationships between the cultivars, the DIST distance coefficient was used, as implemented in the NTSYS-pc package 2.1 developed by Rohlf (Exeter Software, New York, USA, 1993).

For the molecular analysis, the degree of genetic similarity (I) detected between each pair of cultivar studied was calculated using the Simple Matching (SM) coefficient (Sneath and Sokal, 1973) as implemented in the NTSYS-pc package 2.1.

\section{Results and Discussion}

OIV ampelographic descriptor evaluation

According to the PC analysis, which transforms the original data set (OIV descriptors) into a smaller set of uncorrelated new variables (Principal Components, where eigenvalue was bigger than 1), 9 components have been produced in a decline series of their importance, explaining $77.64 \%$ of the total variability among the different cultivars. All descriptors that are grouped in the same principal component have strong correlation between them.

Each component is strongly correlated with a set of the initial OIV descriptors, so their contribution to variability could be estimated.

The OIV descriptors strongly correlated with the 9 components are presented in Table 4 and Fig. 1. For example, and for the cultivars studied, the OIV descriptors 053 (Young leaf: density of prostrate hairs between main veins on lower side of blade (4th leaf)), 004 (Young shoot: density of prostrate hairs on tip), 084 (Mature leaf: density of prostrate hairs between the main veins on lower side of blade), 055 (Young leaf: density of prostrate hairs on main veins on lower side of blade (4th leaf)) contributed better to variability compared to OIV descriptors 223 (Berry: shape), 208 (Bunch: shape).

Cluster analysis separated the varieties in particular groups according to their morphological characteristics: the data from the ampelographic description with the 22 ampelographic descriptors of the varieties studied were used to create a distance matrix in order to generate a dendrogram (Fig. 2). As shown in Fig. 2, the grapevine varieties 'Xinomavro' and 'Zalovitiko' showed identity indicating that they are clones of one initial variety. The

Table 4. Evaluation of the OIV descriptors and their contribution to the variability of the varieties studied

\begin{tabular}{|c|c|c|c|c|c|c|c|c|}
\hline \multicolumn{9}{|c|}{ Principal Components } \\
\hline 1 & 2 & 3 & 4 & 5 & 6 & 7 & 8 & 9 \\
\hline \multicolumn{9}{|c|}{ \% Contribution to variability } \\
\hline 19.52 & 10.19 & 9.39 & 8.32 & 7.15 & 6.97 & 6.08 & 5.21 & 4.77 \\
\hline \multicolumn{9}{|c|}{ Eigenvalue } \\
\hline 4.09 & 2.14 & 1.97 & 1.74 & 1.50 & 1.46 & 1.27 & 1.09 & 1.00 \\
\hline \multicolumn{9}{|c|}{ Related OIV descriptors } \\
\hline 053 & 068 & 079 & 051 & 001 & 067 & 093 & 075 & 223 \\
\hline 004 & 087 & 086 & 231 & 076 & & 070 & & 208 \\
\hline 084 & & 080 & & $081-2$ & & & & \\
\hline 055 & & 225 & & & & & & \\
\hline
\end{tabular}
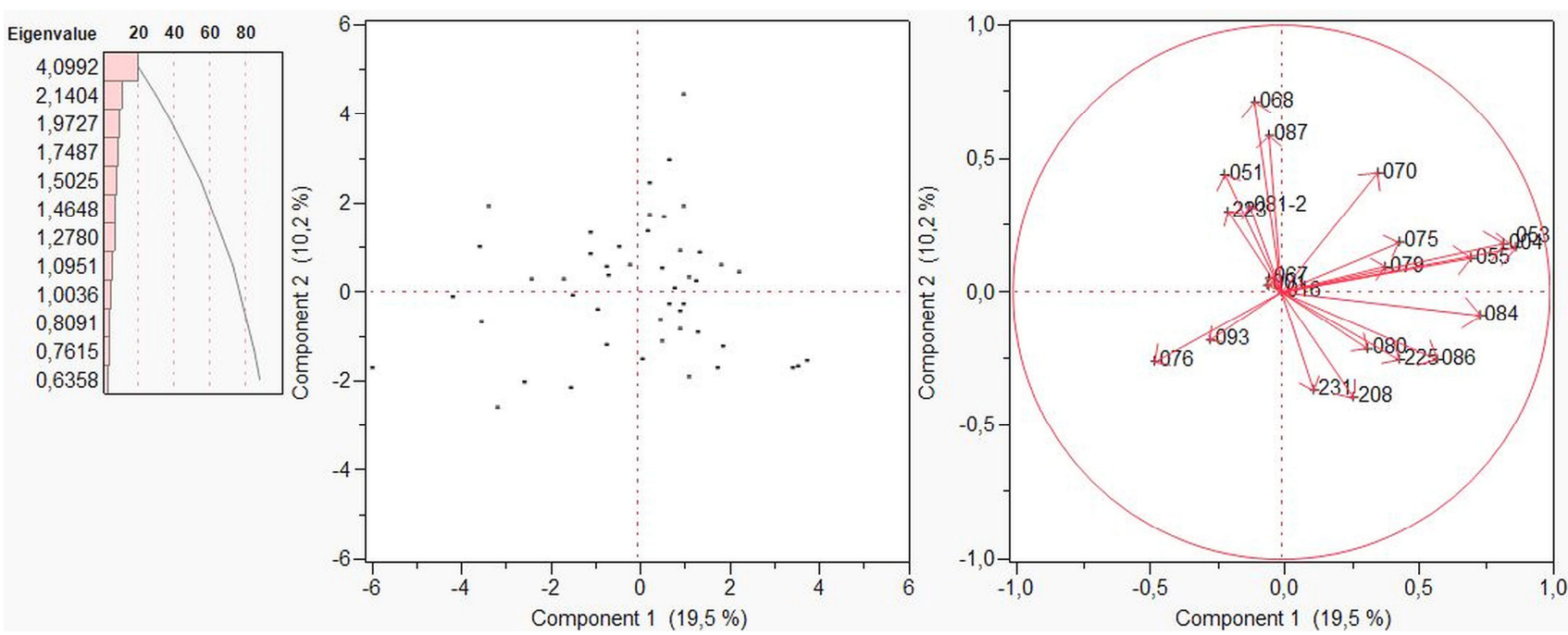

Fig. 1. Evaluation of the OIV descriptors and their contribution to the variability of the cultivars studied 


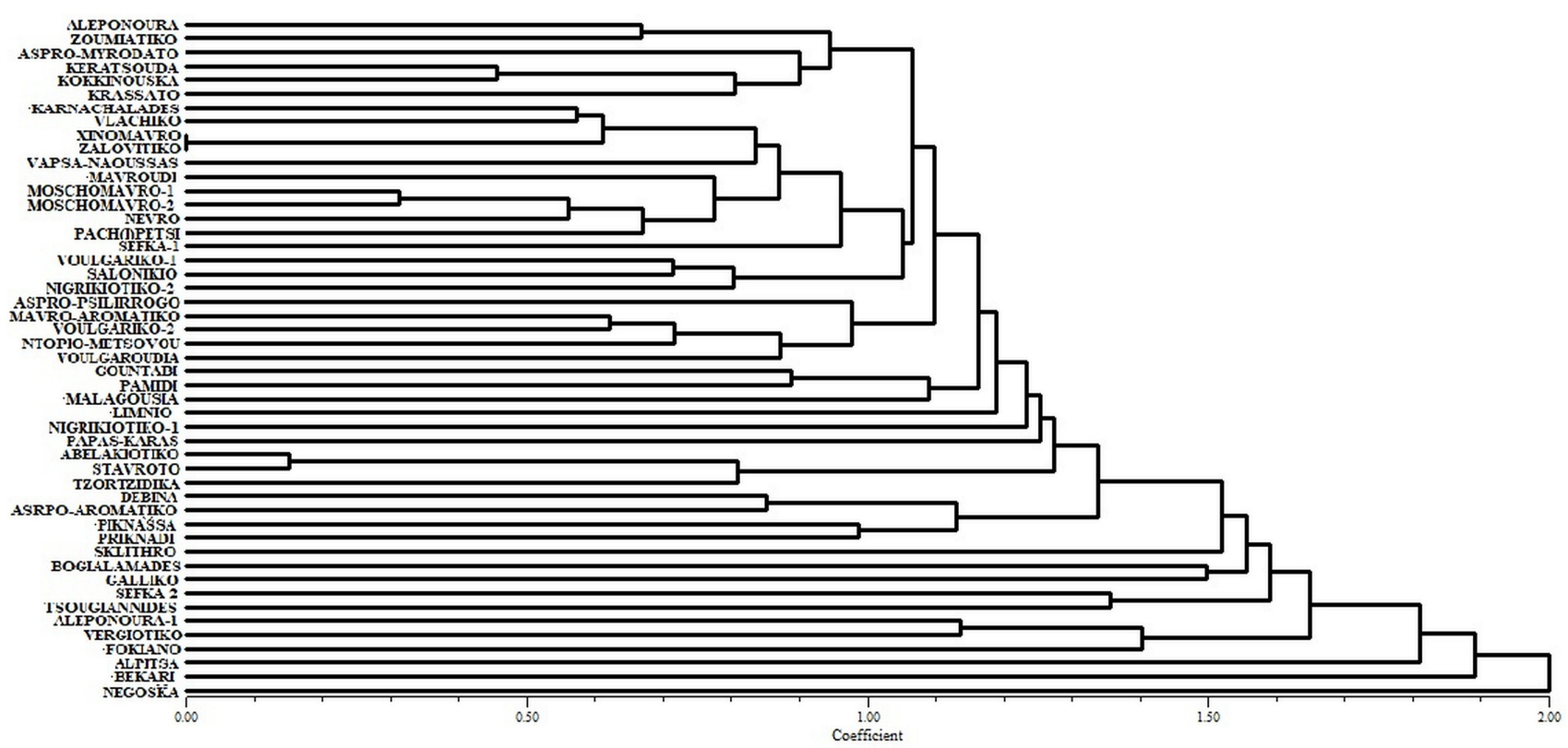

Fig. 2. Dendrogram based on ampelographic descriptors showing the relationship among samples studied (Dissimilarity Coefficient DIST, UPGMA)

very small distances between the cultivars 'Abelakiotiko' and 'Stavroto' (0.15) indicate that they are closely related cultivars which may have originated by the same parent cultivar through the accumulation of mutations. The same holds, but in a smaller degree, between the cultivars/biotypes 'Moschomavro-1', 'Moschomavro-2' (0.31) and 'Keratsouda', 'Kokkinouska' (0.46). On the contrary, grapevine varieties 'Voulgariko-1', 'Voulgariko-2' and 'Voulgaroudia' exhibited relatively large distance between them ranging from 0.92 to 1.01 for the first two, meaning that in spite of their common name, they are in fact different.

Finally, from the group of the varieties that were imported in the viticultural areas of northern Greece ('Galliko', 'Tzortzidika' [synonyms 'Isabella', 'Zabella'], 'Vapsa', 'Bogia' etc.), only 'Sefka-1', 'Sefka-2' and 'Vapsa Naoussas' are grouped in the same cluster of the dendrogram, but they are in fact different.

\section{Molecular analysis}

The results of the molecular analysis, as presented in the dendrogram generated (Fig. 3), confirmed the data of the ampelographic description for most of the studied grapevine varieties.

Particularly regarding grapevine varieties 'Xinomavro' and 'Zalovitiko' which showed identity for the 22 ampelographic characters used, they also exhibited identity with the eight primers used. Therefore, it can be said that these two varieties are one and the same, and that 'Zalovitiko' constitutes synonym/clone of the polyclonal grapevine variety 'Xinomavro'. These results are in disagreement with those of a previous study with the use of molecular method SSR, in which relatively low degree of genetic similarity was recorded between these varieties (Merkouropoulos et al., 2015), something that could be most likely attributed to the fact that different samples were analyzed. 'Zalovitiko' owes its name to the initial cultivation center, Trikomo Grevenon which used to be called Zalovo (zalovitiko $=$ the one coming from Zalovo) (Krimbas, 1944).

The same applies for grapevine varieties 'Xinomavro' and 'Krassato'. In the present study, low degree of genetic similarity was determined between these varieties, placing these varieties in completely different clusters of the dendrogram, confirming the prevailing view that they are indeed different varieties (Kotinis, 1985; Spinthiropoulou, 2000; Nikolaou, 2012; Robinson et al., 2012; Stavrakakis et al., 2018). On the contrary, in a previous study with the use of molecular method SSR, it was suggested that these two varieties are closely related (Merkouropoulos et al., 2015).

High degree of genetic similarity was recorded, as expected, between grapevine cultivars 'Stavroto' and 'Abelakiotiko'. Therefore, they are biotypes/clones of an initial variety ('Stavroto') that originated through the phenomenon of mutation. Despite the differences in ampelographic characters among the biotypes/varieties 'Moschomavro-1' and 'Moschomavro-2', the high degree of genetic similarity $(\mathrm{I}=0.985)$ showed that they are biotypes/clones of an initial variety, confirming the polyclonal synthesis of Greek grapevine varieties (Loukas et al., 1983).

The low degree of genetic similarity as well as the differences in some ampelographic characters show that white grapevine variety 'Aleponoura' (Thr) does not constitute a color mutation of the red grapevine variety 'Aleponoura-1' (wM).

Despite the relatively high degree of genetic similarity, grapevine varieties 'Voulgariko-1', 'Voulgariko-2', 'Voulgaroudia', 'Mavro aromatiko' and 'Mavroudi', independently of their origin, are different. The same applies for grapevine varieties 'Sefka-1', 'Sefka-2' and 'Vapsa Naoussas', confirming the confusion that exists in the nomenclature of these varieties, while grapevine varieties 'Bogia', 'Galliko' and 'Tzortzidika' are also different. Moreover, the low degree of genetic similarity $(\mathrm{I}=0.767)$ among grapevine varieties 'Nigrigiotiko-1' and 
52

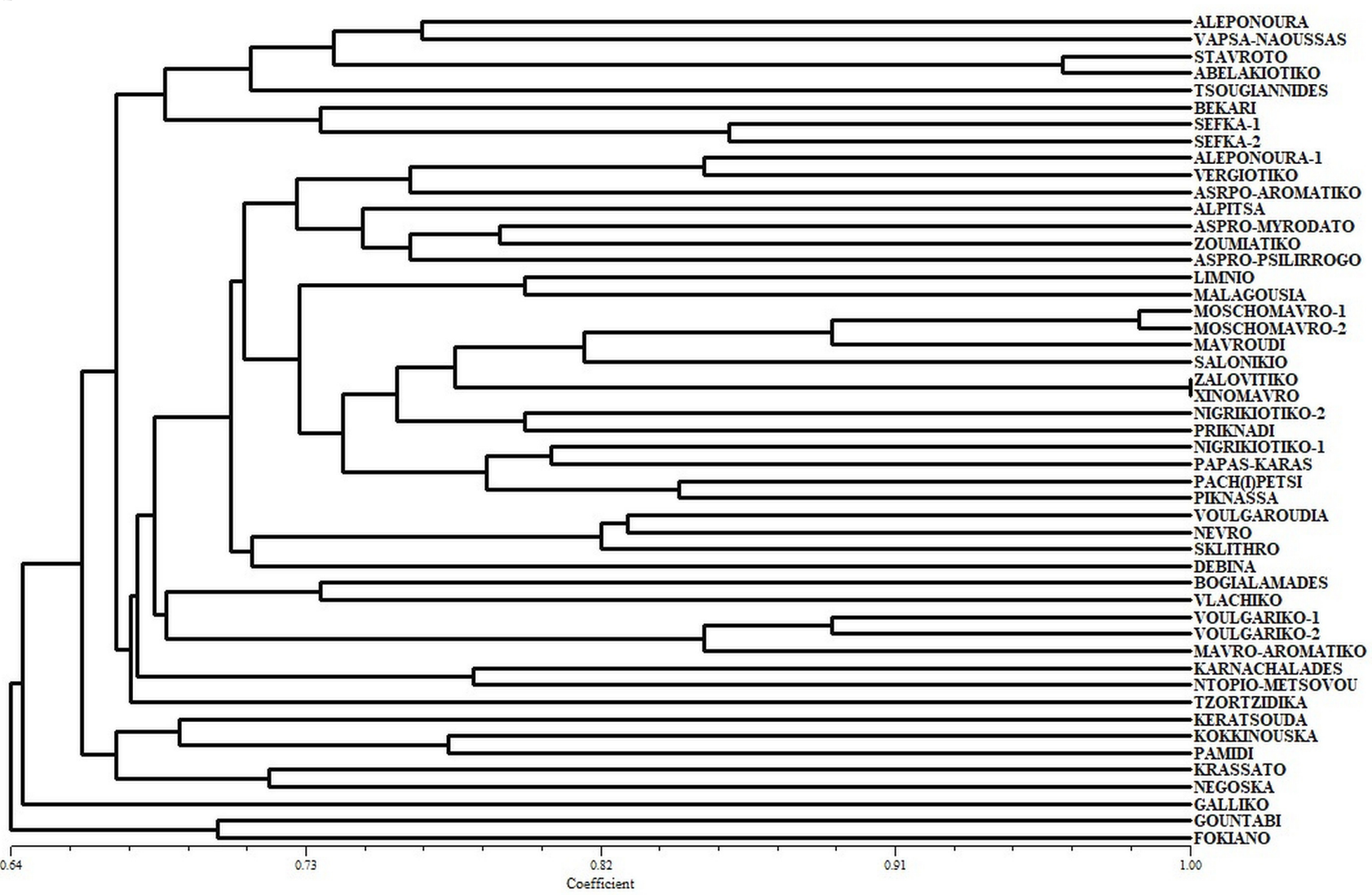

Fig. 3. Dendrogram based on RAPD amplification products showing the relationship among samples studied (Similarity Coefficient Simple Matching, UPGMA)

'Nigrigiotiko-2' confirms the data of the ampelographic description, that they are in fact different varieties that owe their name to the area of origin (Nigrita).

Despite their geographic location, grapevine varieties 'Bekari', 'Debina', 'Gountabi', 'Mavroudi', 'Ntopio Metsovou', 'Pach(i)petsi', 'Piknassa' and 'Vlachiko', which are cultivated in the viticultural area of Epirus, exhibited relatively low degree of genetic similarity, while grapevine varieities 'Karnachalas' (aka 'Karnachalades'), 'Papas-kara' and 'Nigrikiotiko-1', 'Nigrikiotiko-2' are located in the same cluster of the dendrogram, suggesting their possible common origin from eastern Thrace where the first two were mainly cultivated since the $19^{\text {th }}$ century (Hatziparaskevas, 1937/38).

Grapevine variety 'Negoska' differs significantly compared to all other studied varieties and is located in a total different cluster of the dendrogram. It is considered as an indigenous variety of the Macedonian vineyard, with cultivation center being the greater area of Goumenissa (Logothetis, 1955) and participates in the production of PDO wine Goumenissa together with grapevine variety 'Xinomavro'.

Finally, despite the relatively high degree of genetic similarity in the ampelographic characters and characters of the grapes, grapevine varieties 'Pamidi' and 'Keratsouda' are in fact different.

\section{Conclusions}

The results of the present study confirm the genetic heterogeneity as well as the polyclonality of the studied grapevine varieties. At the same time, it is also established that the most efficient way for the identification and discrimination of grapevine varieties is the combination of the ampelographic description with the use of molecular methods.

\section{Acknowledgements}

This research received no specific grant from any funding agency in the public, commercial, or not-for-profit sectors.

\section{References}

Alexiou S (1986). From the Homer' Odyssey Palimpsiston (in Greek).Vikelaia Public Library, Heraklion, Crete.

Davidis OX (1982). Greek Ampelology (in Greek). Band 3, Elements of Ampelography. Athens.

Hatziparaskevas H (1937/38). Viticulture in 40 Eklissies(Kirklareli) (in Greek). Archive of the Thracian Folk and Language Treasure 4:85-100, Athens. 
Kotinis X (1985). Ampelographic Atlas of Greece (in Greek with French summary). Athens.

Kourakou S (2017). Xinomavro. The wine-grape variety of Central-western Macedonia. Publications of Foinikas. Athens.

Krimbas V (1944). Greek Ampelography (Vol. II) (in Greek). Ministry of Agriculture, Athens, Greece.

Krimbas V (1949). Greek Ampelography (Vol. III) (in Greek). Ministry of Agriculture, Athens, Greece.

Lambert-Gòcs M (1990). The wines of Greece. Faber and Faber Ltd. London.

Logothetis B (1955). The wine-grape varieties of Goumenissa, Macedonia (in Greek). Epistemoniki Epetiris tis Geoponikis Sholis University of Thessaloniki3:1-28.

Logothetis BX, Vlachos M (1966). Ampélographie Hellénique (in Greek). Annuaire de la Faculté Agronomique de l'Université de Thessaloniki 377-392.

Loukas M, Stavrakakis MN, Krimbas CB (1983). Inheritance of polymorphic isoenzymes in grape cultivars. The Journal of Heredity 74:181-183.

Merkouropoulos G, Michailidou S, Alifragkis A, Zioziou E, Koundouras S, Argiriou A, Nikolaou N (2015). A combined approach involving ampelographic description, berry oenological traits and molecular analysis to study native grapevine varieties of Greece. Vitis 54:99-103.

Ministry of Rural Development and Food (2017). List of grapevine cultivars recommended and/or authorized for the viticultural areas of Greece (in Greek).Athens.

Nikolaou N (2012). Ampelography (in Greek). Sichroni Paidia Publications, Thessaliniki.

OIV (2009). OIV Descriptor list for grape varieties and Vitis species, 2nd ed. Organisation Internationale de la Vigne et du Vin. Retrieved from http://www.oiv.int/oiv/info/enplubicationoiv.

Polydekfis I (2004). Onomasticon VI 82 (in Greek). Cactus Publications, Athens.

Robinson J, Harding J, Vouillamoz J (2012). Wine Grapes. A Complete Guide to 1,368 Vine Varieties, including their Origins and Flavours. London: Allen Lane(Penguin) and New York: Ecco(HarperCollins).
RohlfFJ (1993). NTSYS-pc. Numerical taxonomy and multivariate analysis system (Version 2.0.2i). Exeter Software, Setauket, New York.

Rusjan D, Bubola M, Janhanin D, UzilaZ, RadekaS, Poljuha D, Pelengic R, Javornik B, Stajner N (2015). Ampelographic characterization of grapevine accessions denominated 'Refošk', 'Refosco', 'Teran' and 'Terrano' (Vitis vinifera L.) from Slovenia, Croatia and Italy. Vitis 54 (Special Issue):77-80.

Sneath PH, Sokal RR (1973). Numerical taxonomy. The principles and practice of numerical classification. Freeman WH and Company, San Francisco and London.

Spinthiropoulou C (2000). Wine grape cultivars of Greek Vineyard (in Greek). Olive Press Publications, Corfu.

Stavrakaki M, Biniari K (2016). Genotyping and phenotyping of twenty old traditional Greek grapevine varieties (Vitis vinifera $\mathrm{L}$.) from Eastern and Western Greece. Scientia Horticulturae 209:86-95.

Stavrakaki M, Biniari K (2017). Ampelographic and Genetic Characterization of Grapevine Varieties (Vitis vinifera L.) of the 'Mavroudia' Group Cultivated in Greece. Notulae Botanicae Horti Agrobotanici 45(2):525-531.

Stavrakakis MN, Biniari K, Hatzopoulos P (1997). Identification and discrimination of eight Greek grape cultivars (Vitis vinifera $\mathrm{L}$.) by random amplified polymorphicDNA markers. Vitis 36(4): 175-178.

Stavrakakis MN (2010). Ampelography (in Greek). Tropi Publications. Athens.

Stavrakakis MN (2017). On names and synonyms of Greek grapevine cultivars (in Greek). Enologia 53:8-12.

Stavrakakis MN, Stavrakaki M, Biniari K, Bouza D (2018). Ampelography of the forgotten Greek grapevine cultivars (in Greek). Tropi Publications. Athens (in press).

Vlachos M(1986).Ampelography (in Greek). Thessaloniki. 